\title{
Increased muscle enzyme activity after yoga breathing during an exacerbation of asthma
}

\author{
FRANK M TAMARIN, RICK CONETTA, ROBERT D BRANDSTETTER, \\ HAL CHADOW
}

From the Division of Pulmonary Diseases, New Rochelle Hospital Medical Center, New Rochelle, New York, USA

ABSTRACT The case is reported of a yoga practitioner who, during an exacerbation of asthma, developed a substantial increase in serum muscle enzymes. This was related to his yoga breathing exercises, which he used to enhance the delivery of aerosolised bronchodilators. As his condition improved and the use of these yoga manoeuvres diminished, the muscle enzyme levels fell to normal.

Mild to moderate increase in serum creatine kinase and other muscle enzyme activities have been reported with both acute and chronic asthma, ${ }^{1-3}$ and independently with the regular practice of yoga. ${ }^{45}$ Substantial increases in muscle enzymes have not been reported in either of these conditions alone or in combination.

\section{Case reports}

A 63 year old yoga enthusiast with a two year history of asthma was admitted with shortness of breath and wheezing of one week's duration. His asthma had been well controlled with oral theophylline (300 $\mathrm{mg}$ thrice daily), salbutamol tablets ( $8 \mathrm{mg}$ thrice daily), and a beclomethasone inhaler. $\mathrm{He}$ claimed that yoga breathing exercises usually alleviated mild attacks of wheezing. On this occasion, however, the exercises were not effective.

Physical examination showed laboured breathing at 32 breaths a minute, a hyperresonant chest, and bilateral diffuse wheezing.

The initial peak expiratory flow (PEF) was $450 \mathrm{l} / \mathrm{min}$, whereas he knew his usual value to be $800 \mathrm{l} / \mathrm{min}$. Arterial blood gas analysis when he was breathing $21 / \mathrm{min}$ of oxygen by nasal cannula showed a $\mathrm{pH}$ of $7 \cdot 45$, an arterial carbon dioxide tension of $4.4 \mathrm{kPa}$, and an arterial oxygen tension of $7.6 \mathrm{kPa}$. The chest radiograph was normal. An electrocardiogram showed sinus tachycardia and was unchanged from the previous one.

Treatment for asthma was begun with an aminophylline infusion, methylprednisolone, nebulised orciprenaline, and oral salbutamol.

On admission serum creatine kinase activity was 777 IU/1, lactic dehydrogenase $207 \mathrm{IU} / \mathrm{l}$, aspartate aminotransferase 37

Address for correspondence: Dr Frank $M$ Tamarin, Division of Pulmonary Diseases, New Rochelle Hospital, New Rochelle, New York, USA. Reprints will not be available.

Accepted 23 March 1988
IU/1, and aldolase $49 \mathrm{U} / 1$ (normal $<8 \mathrm{U} / \mathrm{l}$ ). Creatine kinase activity continued to rise and peaked on the second day with a value of 2273 IU/1 (figure). Isoenzyme analysis showed the creatine kinase and lactic dehydrogenase to originate only from skeletal muscle. Tests for serum rheumatoid factor and antinuclear antibody gave negative results and the urine was free of myoglobin. Creatinine clearance was $99 \mathrm{ml} / \mathrm{min}$. The results of thyroid function tests and the erythrocyte sedimentation rate were normal. The peak flow increased to $5501 / \mathrm{min}$ by the fourth hospital day.

The origin of the increased serum muscle enzyme activities was not clear in the absence of muscle pain, seizure activity, and trauma. When specifically questioned about vigorous physical activity the patient denied conventional exercise but demonstrated his yoga breathing manoeuvres, which consisted of forceful repetitive undulating movements, beginning in the legs and proceeding upwards to include the muscles of the abdomen and chest wall. He practised this strenuous form of breathing during nebuliser treatments for subjective enhancement of their therapeutic effect. As his asthma improved and the use of yoga breathing declined, the activity of serum muscle enzymes returned to normal.

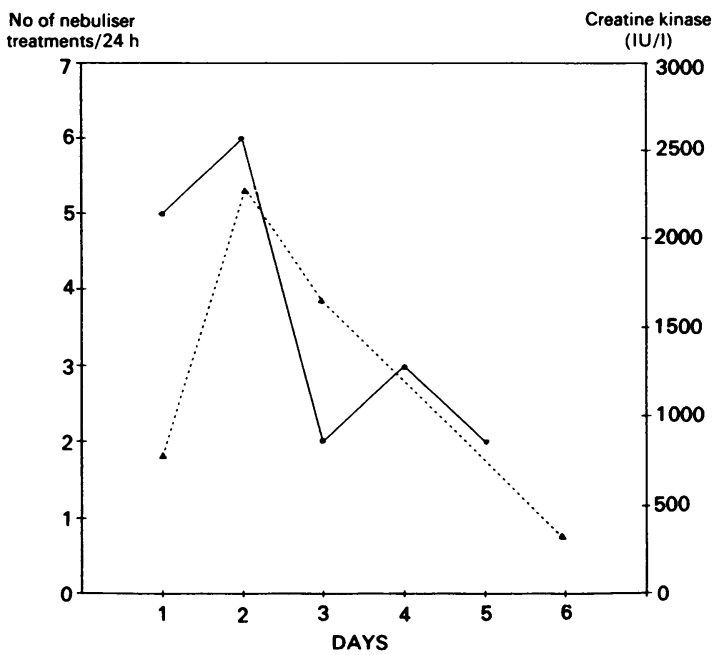

Number of nebuliser treatments and serum creatine kinase activity in relation to time since admission to hospital (day 0). - Nebuliser treatment; - - - - creatine kinase activity. 


\section{Discussion}

Our patient presented with severe bronchoconstriction and greatly increased serum muscle enzymes. There was no history of muscle trauma and other disorders associated with raised enzyme activities, such as hypothyroidism, alcoholism, and pancreatitis, were excluded by appropriate laboratory tests. A relation between strenuous exercise and muscle enzyme increases has been described, ${ }^{6}$ yet our patient had not engaged in any conventional form of exercise. The raised enzyme activities were attributed to the vigorous yoga breathing exercises and the increased work of breathing resulting from his asthma. This form of exertion was most pronounced in the first few days in hospital, when the nebuliser treatments were administered most frequently.

In one Indian study the practice of yoga alone was associated with a four fold increase in serum creatine kinase activity after three months of regular yoga training in novices for one hour a day. ${ }^{4}$ A mild increase in serum lactic dehydrogenase has also been noted in relation to yoga. ${ }^{5}$ Acute attacks of asthma have also been linked with moderate increases in serum muscle enzymes. In one series of untreated patients with acute asthma a mean creatine kinase activity of $202 \mathrm{U} / 1$ and a maximum of $620 \mathrm{U} / 1$ were found. ${ }^{3}$ The increased creatine kinase was thought to be from skeletal muscle and related to the increased work of breathing. In another study patients with acute asthma also showed increased serum creatine kinase originating from skeletal muscle,' which was related directly to severity of symptoms and inversely to $\mathrm{FEV}_{1}$. Some patients with chronic asthma have shown similar results, with creatine kinase values as high as $943 \mathrm{U} / \mathrm{ml}$. Children with severe asthma have also been noted to have mild to moderate increases in serum creatine kinase. $^{7}$

Although there has been some interest in the Indian reports, there have been few formal studies on the effects of yoga on asthma. Two studies have shown improvement in asthma after a short course of yoga instruction, with reduced drug requirements, fewer weekly attacks, and improved peak expiratory flow. ${ }^{89}$
Our patient knew that his baseline peak expiratory flows rate was $800 \mathrm{l} / \mathrm{min}$. On admission the seemingly normal valueo of $450 \mathrm{l} / \mathrm{min}$ did not cause alarm. The respiratory distress, wheezing, and hypoxaemia better defined the severity of hisos asthmatic attack.

We postulate that our patient's yoga breathing techniques during severe bronchoconstriction, which meant vigorousen activity in conjunction with frequent nebuliser treatment, ledto the substantial increase in serum muscle enzymes. Neitherasthma nor yoga alone has been reported to produce $\operatorname{such}_{\vec{\omega}}$ substantial increase in muscle enzymes. This report alsoo underscores the need for physicians to be aware of the patient's usual peak expiratory flow. Because yoga breathing considerably increases physical activity, whether it is safe or beneficial for asthma requires further study.

\section{References}

1 Burki NK, Diamond L Serum creatine phosphokinase activity in asthma. Am Rev Respir Dis 1977;116:327-31.

2 Nevins MA, Saran M, Bright M, Lyon LJ. Pitfalls in inter- $\mathbb{D}$ preting serum creatine phosphokinase activity. JAMA 1973; 224:1382-7.

3 Karetsky MS. Blood studies in untreated patients with acute asthma. Am Rev Respir Dis 1975;112:607-12.

4 Sahay BK, Sadasivudu B, Yogi R, Bhaskaracharyuiu C, Raju PS, Madhavi S, Reddy MV, Annapurna N, Murthy KJR. Biochemical parameters in normal volunteers before and after $\infty$ yogic practices. Indian J Med Res 1982;76(suppl):144-8.

5 Santha J, Sridharan K, Patil SKB, et al. Study of someo physiological and biochemical parameters in subjects undergoing yogic training. Indian J Med Res 1981;74:120-4.

6 Siegel AJ, Silverman LM, Holman BL. Elevated creatine kinase MB isoenzyme levels in marathon runners. Normal myocardial $\mathbb{D}$ scintigrams suggest noncardiac source. JAMA 1981;246: 2049-51.

7 Foy JE, Robbins D. Serum creatine phosphokinase activity in wheezing children. Journal of the American Osteopathy Association 1980;79:376-82.

8 Nagarathna R, Nagendra HR. Yoga for bronchial asthma: a controlled study. Br Med J 1985;291:1077-9.

9 Bradley GW. Yoga for bronchial asthma [letter]. $\mathrm{Br}$ Med J 1985;291:1507. 